\title{
Ineffectiveness of Iodophore Treatment in Disinfecting Salmonid Eggs Carrying Cytophaga psychrophila
}

\author{
Akira Kumagai*1, Kiyotaka Takahashi*2, Shigeto Yamaoka*3 \\ and Hisatsugu Wakabayashi*4 \\ *1 Fisheries Development Division of Miyagi Prefectural Government, \\ Honcho 3, Aoba-ku, Sendai, Miyagi 980-8570, Japan \\ *2Miyagi Prefecture Fisheries Research And Development Center, \\ Watanoha, Ishinomaki Miyagi, 986-2135, Japan \\ ${ }^{*}$ Miyagi Prefectural Freshwater Fisheries Experimental Station, \\ Taiwa, Miyagi 981-3625, Japan \\ ${ }^{* 4}$ Department of Aquatic Bioscience, Graduate School of Agriculutural and Life Sciences, \\ the University of ToKyo, Yayoi 1-1-1, Bunkyo-ku, Tokyo 113-8657, Japan
}

(Received March 30, 1998)

\begin{abstract}
Eggs of coho salmon (Oncorhynchus kisutch), rainbow trout (O. mykiss), and masu salmon (O. masou) were artificially inseminated and subsequently immersed in a modified Ordal and Anacker's broth culture of Cytophaga psychrophila $\left(10^{7}-10^{8} \mathrm{CFU} / \mathrm{ml}\right)$ for $30 \mathrm{~min}$. The bacterium was recovered from the eggs at the eyed stage with viable cell counts ranging from $10^{5}$ to $10^{7} \mathrm{CFU} / \mathrm{g}$. The fertilized eggs were disinfected with $50 \mathrm{ppm}$ povidoneiodine for $15 \mathrm{~min}$ immediately after experimental infection. However, C. psychrophila was detected by a broth culture method from 60-80 percent of the surface-disinfected eggs. At the eyed stage, the eggs were disinfected again with povidone-iodine at concentrations of 50-1,000 ppm for 15-120 min. C. psychrophila was isolated from all of them at densities of $10^{4}-10^{7} \mathrm{CFU} / \mathrm{g}$. The uninfected control eggs were all negative for the bacterium. It is concluded that the povidone-iodine treatment is ineffective to eliminate $C$. psychrophila from salmonid eggs.
\end{abstract}

Key words: cold-water disease, povidone-iodine, salmonid egg, Cytophaga psychrophila, disinfection

The intensive marine farming of coho salmon (Oncorhynchus kisutch) in Japan began in November 1974 (Mahnken 1991). Subsequently, a large number of coho salmon eggs have been imported annually from the Pacific coast of North America, due to lack of the natural stock of this species. The imported eyed eggs are dipped in $50 \mathrm{ppm}$ povidone-iodine for $15 \mathrm{~min}$ immediately after being received at hatcheries. Nevertheless, outbreaks of cold-water disease have often occurred in coho salmon hatcheries since the middle of 1980's (Wakabayashi et al., 1991). Izumi and Wakabayashi (1997) reported that five of nine lots of coho salmon eggs imported from the USA in December 1995 were found to be positive for Cytophaga psychrophila by a polymerase chain reaction method and four of these five lots were also positive by cultivation on TYE agar plates. Outbreaks of cold-water disease occurred only among fry originating from the lots of eggs positive for C. psychrophila by the inspection. Therefore, it was concluded that the disease outbreaks in the hatcheries were caused by the pathogen being accompanied by the imported eggs, even after the eggs were surface-disinfected with povidone-iodine (Kumagai and Takahashi, 1997). Although egg disinfection procedures using organic iodine compound had been recommended, it was noted that iodophore treatment of eggs did not always prevent cold-water disease in subsequent fry (Holt et al., 1993). In a more recent study, Brown et al. (1997) showed the possibility that Flavobacterium psychrophilum (syn. C. psychrophila) might be transmitted within salmonid eggs. The purpose of the present study was to determine whether salmonid eggs were infected with $C$. psychrophila by immersion challenge and whether an iodophore treatment could effectively disinfect the experientially infected eggs.

\section{Materials and Methods}

Susceptibility of C. psychrophila to povidone-iodine Povidone-iodine (Isodine, Meiji Seiyaku Co., Tokyo, 
Japan) was serially diluted 2 -fold with distilled water at available iodine concentrations between 1.25 and 80 $\mathrm{ppm}$. The available iodine concentrations of the solutions were determined by titration with $\mathrm{N} / 10$ sodium thiosulfate.

C. psychrophila strain FPC828 was used in the experiments. This strain had been originally isolated from the kidney of coho salmon fry in Miyagi, Japan in 1990 (Wakabayashi et al., 1991). The bacterium was grown in a modified Ordal and Anacker's agar (tryptone $0.3 \%$, yeast extract $0.2 \%$, beef extract $0.02 \%$, sodium acetate $0.02 \%$, agar $1.5 \%, \mathrm{pH} 7.2$ ) at $15^{\circ} \mathrm{C}$ for 5 days. The bacterial cells collected from the colonies were suspended in phosphate-buffered saline (PBS) at a density of $7.5 \times 10^{7} \mathrm{CFU} / \mathrm{ml}$. A half milliliter of the bacterial suspensions was mixed with an equal volume of the serial 2-fold dilutions of povidone-iodine in a 24 well mirotitration plate. Following $0.5,1,2.5,5$, and $15 \mathrm{~min}$ of incubation at $15^{\circ} \mathrm{C}$, the iodine was neutralized with $0.1 \mathrm{ml}$ of $\mathrm{N} / 10$ sodium thiosulfate, and then a 0.1 $\mathrm{ml}$ aliquot of the mixture from each well was inoculated on a TY agar plate (tryptone $0.3 \%$, yeast extract $0.2 \%$, $\mathrm{pH} 7.5$ ). After 7 days of incubation at $15^{\circ} \mathrm{C}$, the growth of $C$. psychrophila was recorded.

\section{Experimental infection of eggs with C. psychrophila}

Eggs were collected from mature coho salmon, rainbow trout (Oncorhynchus mykiss), and masu salmon (Oncorhynchus masou) which had been kept in Miyagi Prefectural Freshwater Fisheries Experimental Station. The eggs of each fish were artificially inseminated in a glass bowl. Excess milt was rinsed off three times with PBS. Eggs were divided into four groups of 400 eggs.

C. psychrophila strain FPC828 was cultivated in a modified Ordal and Anacker's broth (tryptone 0.3\%, yeast extract $0.2 \%$, beef extract $0.02 \%$, sodium acetate $0.02 \%, \mathrm{pH} 7.2$ ) at $15^{\circ} \mathrm{C}$ for 3 days. Before water hardening, two of the four egg groups were immersed in 200 $\mathrm{ml}$ of the broth culture $\left(1.4 \times 10^{7}-7.1 \times 10^{8} \mathrm{CFU} / \mathrm{ml}\right)$ for $30 \mathrm{~min}$. After the treatments, each batch of eggs was discretely incubated in flowing water at $8 \pm 1^{\circ} \mathrm{C}$ at the rate of about $0.5 \mathrm{l} / \mathrm{min}$. The other two control groups were bathed in PBS for 30 min before incubation.

Eggs were sampled immediately after experimental infection and at the eyed stage (28-42 days of incubation). At each sampling time, 10 eggs were removed at random from each group and homogenized with a sterile glass rod. The homogenate was then serially diluted 10-fold with PBS. Twenty-five microliter of each diluted sample was dropped, in triplicate, onto an enriched Ordal and Anacker's agar plates (Lorenzen and Karas, 1992). The plate were incubated at $15^{\circ} \mathrm{C}$ for 7 days, after which colonies were counted. The detection limit by this plate counting method was estimated to be $4.0 \times 10^{3} \mathrm{CFU} / \mathrm{g}$-egg. For coho salmon, 30 eggs were sampled again at 50 days of incubation, and examined individually for $C$. psychrophila in the same manner as above.

\section{Disinfection of eggs with povidone-iodine just after bac- terial infection}

The eggs were disinfected with $50 \mathrm{ppm}$ povidoneiodine for $15 \mathrm{~min}$ following the above-mentioned experimental infection. Duplicate sets of each group were separately incubated in flowing hatchery water. Ten eggs were sampled from each group at the beginning of incubation and at the eyed stage. The bacteriological examination was undertaken on the pooled 10 eggs.

An additional experiment using coho salmon eggs was performed in order to improve the detection method of C. psychrophila. The surface-disinfected eggs were divided into 5 groups of 5 eggs each. The eggs of each group were pooled into a sterile glass tube, washed with sterile PBS, and homogenized with a sterile glass rod. The homogenates were serially diluted ten-fold with PBS and $0.3 \mathrm{ml}$ of each dilution was inoculated into a modified Ordal and Anacker's broth, which was incubated at $15^{\circ} \mathrm{C}$ for 7 days. The broth culture were smeared on glass slides. After being fixed with aceton, the specimens were examined for $C$. psychrophila by indirect fluorescent antibody technique (IFAT). This broth culture method raised the detection limit to $3.3 \times 10$ CFU/g-egg, comparing to the plate count.

\section{Disinfection of eggs with povidone-iodine at the eyed stage}

The fertilized eggs of coho salmon, rainbow trout, and masu salmon were experimentally infected with $C$. psychrophila $\left(1.4 \times 10^{7}-7.1 \times 10^{8} \mathrm{CFU} / \mathrm{ml}\right)$ as described above, incubated at $8 \pm 1{ }^{\circ} \mathrm{C}$, and disinfected with povidone-iodine at the eyed stage. The following 4 experiments were carried out: 1) Eight groups of 10 coho salmon eggs each were immersed in $10 \mathrm{ml}$ of povidoneiodine solutions at concentrations of $0,50,100,200,400$, 600,800 and $1000 \mathrm{ppm}$, respectively, for $15 \mathrm{~min}$. 2) Sixteen groups of 10 coho salmon eggs each were immersed in $10 \mathrm{ml}$ of $0,50,100$ and $200 \mathrm{ppm}$ povidoneiodine, respectively, for $15,30,60$ and $120 \mathrm{~min}$, respec- 
tively. 3) Three groups of 10 rainbow trout eggs each were immersed in $10 \mathrm{ml}$ of 0,100 and $200 \mathrm{ppm}$ povidone-iodine, respectively, for $15 \mathrm{~min}$. 4) Three groups of 10 masu salmon eggs each were immersed in $10 \mathrm{ml}$ of 0,100 and $200 \mathrm{ppm}$ povidone-iodine, respectively, for $15 \mathrm{~min}$. Each experiment was performed in duplicate. After iodophore treatment, the eggs were rinsed three times with $10 \mathrm{ml}$ of PBS, and then the bacteriological examination was made on each sample in the same manner as above.

\section{Results}

Susceptibility of C. psychrophila to povidone-iodine

Povidone-iodine solutions killed completely $C$. psychrophila at the available iodine concentration of 20 ppm in $1.0 \mathrm{~min}$ or $40 \mathrm{ppm}$ in $0.5 \mathrm{~min}$. However, the bacterium was resistant to $10 \mathrm{ppm}$ povidone-iodine for 15 min (Table 1).

\section{Experimental infection of eggs with C. psychrophila}

C. psychrophila was isolated not only from eggs just after being exposed to the bacterium but also from the eggs at the eyed stage. The numbers of live $C$. psychrophila cells recovered were alwasy larger in the
Table 1. Bactericidal effect of povidon-iodine on C.psychrophila

\begin{tabular}{cccccc}
\hline \hline $\begin{array}{c}\text { Povidone-iodine } \\
\text { concentration } \\
(\mathrm{ppm})\end{array}$ & 0.5 & 1.0 & 2.5 & 5.0 & 15.0 \\
\cline { 2 - 6 } & \multicolumn{5}{c}{ Exposure time (min) } \\
0.63 & - & - & - & - & - \\
1.25 & - & - & - & - & - \\
2.5 & - & - & - & - & - \\
5.0 & - & - & \pm & \pm & \pm \\
10.0 & \pm & \pm & \pm & \pm & \pm \\
20.0 & \pm & + & + & + & + \\
40.0 & + & + & + & + & + \\
\hline
\end{tabular}

+ Effective (No CFU after exposure)

\pm Incompletely effective (Reduction of CFU after exposure)

- Ineffective (Hardly reduction of CFU after exposure)

eyed eggs (Table 2). C. psychrophila was still isolated from $70 \%$ of coho salmon eggs (21/30) at 50 days of incubation and the viable bacterial counts ranged from $2.6 \times 10^{5}$ to $6.6 \times 10^{7} \mathrm{CFU} / \mathrm{g}\left(6.1 \times 10^{6} \mathrm{CFU} / \mathrm{g}\right.$ in average) (Fig. 1).

\section{Disinfection of eggs with povidone-iodine just after bac- terial infection}

No C. psychrophila was detected from the eggs of

Table 2. The numbers of live $C$. psychrophila cells recovered from salmonid eggs exposed to the bacterial suspension

\begin{tabular}{|c|c|c|c|c|}
\hline \multirow[b]{2}{*}{ Fish } & \multirow[b]{2}{*}{ Group } & & \multicolumn{2}{|c|}{ Number of live $C$. psychrophila cells } \\
\hline & & & $\begin{array}{l}\text { Eggs at the beginning } \\
\text { of incubation }\end{array}$ & Eggs at the eyed stage*1 \\
\hline \multirow[t]{4}{*}{ Coho salmon } & Experimentally & 1 & $5.9 \times 10^{5 * 2}$ & $1.6 \times 10^{6}$ \\
\hline & infected & 2 & $5.8 \times 10^{5}$ & $3.2 \times 10^{6}$ \\
\hline & Uninfected- & 1 & - ${ }^{* 3}$ & - \\
\hline & control & 2 & - & - \\
\hline \multirow[t]{4}{*}{ Rainbow trout } & Experimentally & 1 & $2.0 \times 10^{6}$ & $4.0 \times 10^{7}$ \\
\hline & infected & 2 & $2.8 \times 10^{6}$ & $4.4 \times 10^{7}$ \\
\hline & Uninfected- & 1 & - & - \\
\hline & control & 2 & - & - \\
\hline \multirow[t]{4}{*}{ Masu salmon } & Experimentally & 1 & $1.2 \times 10^{5}$ & $4.0 \times 10^{6}$ \\
\hline & infected & 2 & $1.6 \times 10^{5}$ & $5.6 \times 10^{6}$ \\
\hline & Uninfected- & 1 & - & - \\
\hline & control & 2 & - & - \\
\hline
\end{tabular}

*1 The eggs of coho salmon, rainbow trout and masu salmon were examined at 42,28 and 35 days of incubation, respectively.

*2 Bacterial numbers were expressed in CFU/g.

*3 Not detected. The lower limit of detection was $4.0 \times 10^{3} \mathrm{CFU} / \mathrm{g}$. 


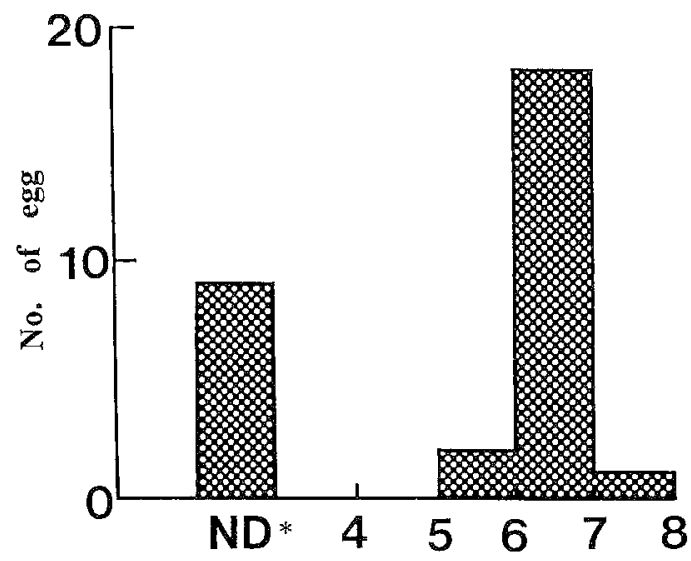

Viable bacterial counts ( $\mathrm{Log} \mathrm{CFU} / \mathrm{g}$ )

Fig. 1. Viable bacterial counts in coho salmon eyed eggs which had been exposed to C. psychrophila just after fertilization.

* Not detected.

coho salmon, rainbow trout, and masu salmon, which were disinfected with povidon-iodine ( $50 \mathrm{ppm}, 15 \mathrm{~min}$ ) immediately after bacterial infection. However, the bacterium was isolated from the eyed eggs of all these fishes at a considerable density. C. psychrophila was not detected from all the uninfected control groups (Table 3).

The broth culture method was capable of detecting $C$. psychrophila from the fertilized eggs which were negative for the bacterium in the plate count method. Sixty to eighty percent of the surface-disinfected eggs were positive for C. psychrophila at the beginning of incubation. Uninfected control eggs were all negative for the bacterium (Table 4 ).

\section{Disinfection of eggs with povidone-iodine at the eyed stage}

C. psychrophila was isolated from all the eyed eggs which had been surface-disinfected at various concentrations of povidone-iodine just before examined. Even if the coho salmon eggs were disinfected with $1,000 \mathrm{ppm}$ povidone-iodine, the bacterium persisted at the density of $4.0 \times 10^{4}$ or $8.0 \times 10^{4} \mathrm{CFU} / g$-egg. There was no significant difference in the number of recovered bacterial cells between iodophore concentrations. Moreover, the viable bacterial counts of the surface-disinfected eggs were almost same as that of non-disinfected control eggs (Table 5). The exposure time to povidone-

Table 3. Detection of C. psychrophila from salmonid eggs disinfected with povidone-iodine just after bacterial infection

\begin{tabular}{|c|c|c|c|c|}
\hline \multirow[b]{2}{*}{ Fish } & \multirow[b]{2}{*}{ Group } & & \multicolumn{2}{|c|}{ Number of live C. psychrophila cells } \\
\hline & & & $\begin{array}{l}\text { Eggs at the beginning } \\
\text { of incubation }\end{array}$ & Eggs at the eyed stage*:1 \\
\hline \multirow{4}{*}{$\begin{array}{l}\text { Coho } \\
\text { salmon }\end{array}$} & Experimentally & 1 & —*3 & $4.4 \times 10^{5 * 2}$ \\
\hline & infected & 2 & - & $4.4 \times 10^{5}$ \\
\hline & Uninfected- & 1 & - & 一 \\
\hline & control & 2 & - & - \\
\hline \multirow{4}{*}{$\begin{array}{l}\text { Rainbow } \\
\text { trout }\end{array}$} & Experimentally & 1 & - & $4.0 \times 10^{6}$ \\
\hline & infected & 2 & 一 & $4.0 \times 10^{7}$ \\
\hline & Uninfected- & 1 & - & 一 \\
\hline & control & 2 & 一 & - \\
\hline \multirow{4}{*}{$\begin{array}{l}\text { Masu } \\
\text { salmon }\end{array}$} & Experimentally & 1 & - & $8.0 \times 10^{6}$ \\
\hline & infected & 2 & - & $4.4 \times 10^{6}$ \\
\hline & Uninfected- & 1 & - & - \\
\hline & control & 2 & - & - \\
\hline \multicolumn{5}{|c|}{$\begin{array}{l}* 1 \text { The eggs of coho salmon, rainbow trout and masu salmon were examined at } 42,28 \text { and } \\
35 \text { days of incubation, respectively. }\end{array}$} \\
\hline \multicolumn{5}{|c|}{ *2 The bacterial numbers were expressed in CFU/g. } \\
\hline
\end{tabular}


iodine had also nothing to do with the number of live $C$ psychrophila cells recovered from the surface-disinfected eggs (Table 6).

\section{Discussion}

In the experimental infection of fertilized eggs with C. psychrophila, no bacteria could be isolated from the

Table 4. Comparison of methods in the detection of $C$. psychrophila from coho salmon eggs disinfected with povidone-iodine just after bacterial infection

\begin{tabular}{lccc}
\hline \hline \multirow{2}{*}{ Group } & \multicolumn{2}{c}{ Detection of C. psychrophila by } \\
\cline { 2 - 4 } & Plate count *1 & Broth culture *2 \\
\hline Experimentally & 1 & $0 / 5^{* 3}$ & $4 / 5$ \\
infected & 2 & $0 / 5$ & $3 / 5$ \\
\hline Uninfected - control & 1 & $0 / 5$ & $0 / 5$ \\
& 2 & $0 / 5$ & $0 / 5$ \\
\hline
\end{tabular}

*1 The detection limit was $4.0 \times 10^{3} \mathrm{CFU} / \mathrm{g}$.

*2 The detection limit was $3.3 \times 10 \mathrm{CFU} / \mathrm{g}$.

*3 Number of eggs positive for C. psychrophila/number of eggs examined. non-infected control groups, whereas a large number of the bacteria was recovered from the infected groups at the eyed stage as well as at the beginning of incubation. This result indicated that experimental infection of eggs with $C$. psychrophila was succesful by immersing the fertilized eggs (befofe water-hardening) in broth culture.

Disinfection of fertilized eggs with povidone-iodine following experimental infection with $C$. psychrophila revealed that the iodophore treatment reduced the live bacterial number but the killing effect was not complete. Sixty or eighty percent of the surface-disinfected eggs were positive for $C$. psychrophila, and the number of viable bacterial cells was estimated to be $3.3 \times 10-4 \times$ $10^{3} \mathrm{CFU} / \mathrm{g}$-egg. The number of bacteria reached $10^{4}$ $10^{7} \mathrm{CFU} / \mathrm{g}$-egg at the eyed stage. Lorenzen (1994) reported that disinfection with Aktomar K30 (22 and 66 ppm I2) just after infection could not remove $C$. psychrophila from experimentally infected eggs.

Disinfection of the experimentally infected eggs at the eyed stage with povidone-iodine resulted in no reduction in the number of live $C$. psychrophila, even if they were exposed high iodophore concentrations. These results indicate that $C$. psychrophila may be located at the inner part of the eggs where povidone-iodine cannot

Table 5. Detection of $C$. psychrophila from salmonid eggs disinfected with povidone-iodine at the eyed stage

\begin{tabular}{|c|c|c|c|c|}
\hline \multirow{2}{*}{$\begin{array}{l}\text { Povidone-iodine } \\
\text { concentration } \\
(\mathrm{ppm})\end{array}$} & \multirow{2}{*}{ Group } & \multicolumn{3}{|c|}{ Number of $C$. psychrophila recovered from eyed eggs } \\
\hline & & Coho salmon & Rainbow trout & Masu salmon \\
\hline \multirow[t]{2}{*}{0} & 1 & $4.0 \times 10^{4 * 1}$ & $4.0 \times 10^{7}$ & $8.0 \times 10^{6}$ \\
\hline & 2 & $8.0 \times 10^{5}$ & $4.4 \times 10^{7}$ & $4.0 \times 10^{6}$ \\
\hline \multirow[t]{2}{*}{50} & 1 & $8.0 \times 10^{5}$ & $\mathrm{NT}^{* 2}$ & NT \\
\hline & 2 & $4.0 \times 10^{5}$ & NT & NT \\
\hline \multirow[t]{2}{*}{100} & 1 & $4.0 \times 10^{5}$ & $1.7 \times 10^{7}$ & $1.6 \times 10^{6}$ \\
\hline & 2 & $8.0 \times 10^{4}$ & $4.0 \times 10^{6}$ & $8.0 \times 10^{6}$ \\
\hline \multirow[t]{2}{*}{200} & 1 & $4.0 \times 10^{5}$ & $1.4 \times 10^{7}$ & $1.2 \times 10^{6}$ \\
\hline & 2 & $3.6 \times 10^{5}$ & $8.0 \times 10^{5}$ & $1.6 \times 10^{7}$ \\
\hline \multirow[t]{2}{*}{400} & 1 & $2.4 \times 10^{5}$ & NT & NT \\
\hline & 2 & $4.8 \times 10^{5}$ & NT & NT \\
\hline \multirow[t]{2}{*}{600} & 1 & $4.0 \times 10^{5}$ & NT & NT \\
\hline & 2 & $8.0 \times 10^{5}$ & NT & NT \\
\hline \multirow[t]{2}{*}{800} & 1 & $8.0 \times 10^{3}$ & NT & NT \\
\hline & 2 & $4.4 \times 10^{5}$ & NT & NT \\
\hline \multirow[t]{2}{*}{1,000} & 1 & $4.0 \times 10^{4}$ & NT & NT \\
\hline & 2 & $8.0 \times 10^{4}$ & NT & NT \\
\hline
\end{tabular}

*1 Bacterial counts were expressed in CFU/g. The detection limit was $4.0 \times 10^{3} \mathrm{CFU} / \mathrm{g}$.

*2 Not tested 
Table 6. Detection of $C$. psychrophila from coho salmon eggs disinfected with povidoneiodine at the eyed stage*1

\begin{tabular}{cccccc}
\hline \hline $\begin{array}{c}\text { Povidone-iodine } \\
\text { concentration } \\
(\mathrm{ppm})\end{array}$ & Group & \multicolumn{4}{c}{ Exposure time (min) } \\
\cline { 3 - 6 } & 1 & $3.6 \times 10^{5 * 2}$ & $\mathrm{NT} * 3$ & $\mathrm{NT}$ & $\mathrm{NT}$ \\
\hline 0 & 2 & $8.0 \times 10^{6}$ & $\mathrm{NT}$ & $\mathrm{NT}$ & $\mathrm{NT}$ \\
& 1 & $1.6 \times 10^{6}$ & $9.7 \times 10^{5}$ & $1.2 \times 10^{6}$ & $2.9 \times 10^{6}$ \\
50 & 2 & $3.2 \times 10^{6}$ & $1.5 \times 10^{6}$ & $3.8 \times 10^{6}$ & $6.0 \times 10^{6}$ \\
& 1 & $5.0 \times 10^{5}$ & $3.6 \times 10^{6}$ & $3.4 \times 10^{5}$ & $1.1 \times 10^{6}$ \\
100 & 2 & $1.5 \times 10^{6}$ & $4.0 \times 10^{5}$ & $2.7 \times 10^{7}$ & $1.1 \times 10^{6}$ \\
& 1 & $9.7 \times 10^{5}$ & $1.6 \times 10^{6}$ & $1.2 \times 10^{6}$ & $8.0 \times 10^{4}$ \\
200 & 2 & $1.5 \times 10^{6}$ & $4.9 \times 10^{5}$ & $9.2 \times 10^{4}$ & $1.6 \times 10^{5}$ \\
\hline
\end{tabular}

*1 At 41 days of incubation

*2 Bacterial numbers were expressed in CFU/g. The detection limit was $4.0 \times 10^{3}$ CFU/g.

*3 Not tested

reach. Brown et al (1997) showed the evidence that $C$. psychrophila was transmitted within salmonid eggs. They speculated that the bacterium might be located within the peri-vetellin space of the eggs, rather than the yolk itself. Further work to find C. psychrophila's niche within salmonid eggs is needed.

\section{Acknowledgments}

The authors thank the staff of Miyagi Prefectural Freshwater Fisheries Experimental Station for their kind cooperation. This study was partially supported by a grant from the Ministry of Agriculture, Forestry, and Fisheries of Japan.

\section{References}

Brown, L. L., W. T.Cox and R. P. Levine (1997): Evidence that the causal agent of bacterial cold-water disease Flavobacterium psychrophilum is transmitted within salmonid eggs. Dis. Aquat. Org., 29, 213-218.

Holt, R. A., J. S. Rohovec and J. L. Fryer (1993): Bacterial cold-water disease. In: (ed. by "Bacterial diseases of fish," V. Inglis, R. J. Roberts and N. R. Bromage). Blackwell Scientific Publications, Oxford, pp. 3-23.

Izumi, S. and H. Wakabayashi (1997): Use of PCR to detected Cytophaga psychrophila from apparently healthy juvenile ayu and coho salmon. Fish Pathol., 32, 169-173.

Kumagai, A. and K. Takahashi (1997): Imported eggs responsible for the outbreaks of cold-water disease among cultured coho salmon in Japan. Fish Pathol., 32, 231-232.

Lorenzen, E. (1994): Studies on Flexibacter psychrophilus in relation to rainbow trout fry syndrome (RTFS). $\mathrm{Ph}$. D. Thesis. The Royal Veterinary and Agricultural University, Copenhagen.

Lorenzen, E. and N. Karas (1992): Detection of Flexibacter psychrophilus by immuno-fluorescence in fish suffered from fry mortality syndrome: a rapid diagnostic method. Dis. Aquat. Org., 13, 231-234

Mahnken, C. V. W. (1991): Coho salmon farming in Japan. In: R. R. Stickney (ed.). Culture of salmonid fishes. CRC Press, Florida, USA, p. 131-149.

Wakabayashi, H., M.Horiuchi, T. Bunya and G. Hoshiai (1991): Outbreaks of cold-water disease in coho salmon in Japan. Fish Pathol., 26, 211-212. 